\title{
POLLEN MORPHOLOGY OF THE POLISH SPECIES OF THE GENUS SORBUS L.
}

\author{
LESZEK BEDNORZ1 ${ }^{1}$, IRMINA MACIEJEWSKA-RUTKOWSKA ${ }^{2}$, \\ DOROTA WrońSKA-PILAREK ${ }^{3}$, TOSHIYUKI FUJIKI ${ }^{4}$ \\ ${ }^{1}$ Department of Botany, August Cieszkowski Agricultural University \\ Wojska Polskiego 71 C, 60-625 Poznań, Poland \\ e-mail: lbednorz@au.poznan.pl \\ ${ }^{2,3}$ Department of Forest Botany, August Cieszkowski Agricultural University \\ Wojska Polskiego 71 D, 60-625 Poznań, Poland \\ ${ }^{4}$ Nagoya University, Graduate School of Environmental Studies, School of Sciences \\ Furo-cho, Chikusa-ku Nagoya City, 464-8601 Japan
}

(Received: February 11, 2005. Accepted: April 27, 2005)

\begin{abstract}
This paper presents the results of the study on pollen morphology of five Polish species of the genus Sorbus L. ( $S$. aria (L.) Crantz, S. aucuparia L. Emend. Hedl., S. chamaemespilus (L.) Crantz, S. intermedia (Ehrh.) Pers. and $S$. torminalis (L.) Crantz). Observations were carried out with light and scanning microscopes. Investigated pollen grains were small or medium size, most often subprolate or prolate spheroidal in outline. Exine of medium thickness, consisted of two layers. Mainly 3-zonocolporate or sometimes 4-zonocolporate (S. chamaemespilus and S. torminalis) grains were noted. Usually striatae type of sculpture was observed, except the grains of S. intermedia, which were characterized by intermediate type of sculpture, with the features both striate and regulate ornamentation.

Pollen morphology of the investigated Sorbus species corresponds with their systematic classification. It is relatively easy to separate pollen grains of the following subgenera: Sorbus, Chamaemespilus and Torminaria. Only subgenus Aria includes grains of different morphology and therefore it is impossible to determine the diagnostic features of this subgenus. Pollen morphology does not confirm a close relationship between $S$. aria and $S$. intermedia.

It is possible to distinguished pollen grains of all the analysed native species. However, there are no important differences in pollen morphology between the subspecies of Sorbus aucuparia. The key for Polish Sorbus species, based on pollen grain characters is given too.
\end{abstract}

KEY WORDS: Sorbus, pollen morphology, palynotaxonomy, SEM, LM.

\section{INTRODUCTION}

Studies on pollen morphology of European species of the genus Sorbus showed their considerable similarity to pollen grains of other taxa of the Rosaceae family, as Crataegus, Malus, Pyrus, Dryas, Prunus and Aronia (Teppner 1965; Reitsma 1966; Eide 1981; Moore et al. 1991, Faegri and Iversen 1992). All those mentioned species belong to the trizonocolporate class of pollen and the lack of operculum and costae colpi are considered to be the most important features, differentiating them from the other representatives of Rosaceae.

Older palynological investigations, carried out only with the use of LM, have proposed to include Sorbus grains into morphological type of Crataegus (Faegri and Iversen 1964; Reitsma 1966). However, according to Gabrielian (1978), it is possible to separate within this genus a num- ber of pollen types, using exclusively LM. The cited author (1.c.) observing pollen of 40 species, originating from western Asia and of Himalayas, distinguished 17 morphological types of grains. She recognized shape and size of grains, number, structure and shape of apertures, exine thickness and sculpture type, as diagnostic features of the genus. Gabrielian (1.c.) also noticed that it was relatively easy to separate the so called 'good species', which usually were diploids and had got pollen of high vitality. On the other hand, within the genus Sorbus, the hybrids and polyploids produce pollen in high percentage sterile.

Moore and others (1991) have emphasized the very large differentiation of pollen morphology of the taxa of Rosaceae family, even among the populations within the same species. They thought the grain size to be the least reliable feature and they related it to the comparatively frequent occurrence of hybrid and polyploid species in this family. 
In the key to pollen grains of north-west European species the cited authors divided taxa of Maloideae subfamily into two groups. Sorbus aucuparia, S. rupicola and S. torminalis (together with Malus sylvestris and Pyrus pyraster) comprise the first group, and S. aria and poliploids of the Sorbus (with Crataegus monogyna and C. laevigata) - the second.

Many palynological studies showed that the interpretation of exine ornamentation in Sorbus species was very difficult to carry out just with the use of light microscope. For instance Praglowski (1962), observing pollen grains of $S$. aucuparia distinguished a striate type of ornamentation, with very gentle striae. According to Stachurska and others (1973), the sculpture in this species was faintly granular and slightly striatae. Instead, Boyd and Dickson (1986) described the exine sculpture of S. aucuparia as psilate, finely stippled and with slightly beaded striations.

Faultless qualification of sculpture character of pollen grains of particular Sorbus species is possible using scanning microscope, what illustrates Eide's work (1981). The author proved that striate ornamentation with distinct muri was a characteristic feature of pollen grains of four Sorbus species (S. arranensis, S. aucuparia, S. hybrida and S. rupicola). Eide (1.c.) thought exine ornamentation to be one of the most important diagnostic features, not only with re- gard to the taxa of Sorbus, but also with regard to other genera within the Rosaceae family.

Within the area of Poland, till now pollen grains of four Sorbus species occurring in the wild: S. aria, S. aucuparia, $S$. chamaemespilus and $S$. torminalis and of one cultivated species: $S$. domestica, have been described by means of light microscope (Stachurska et al. 1973). From among those native species only pollen morphology of $S$. aucuparia was investigated in SEM (Eide 1981; Moore et al. 1991), but the analysed pollen samples originated from north-west Europe.

The main aim of the present work was to describe pollen morphology of the native species of genus Sorbus, both in SEM and LM. The authors also wanted to evaluate the utility of pollen features in identification of the examined species and in taxonomy of genus Sorbus.

\section{MATERIALS AND METHODS}

Pollen grains of five Sorbus species naturally occurring in Poland were investigated. They represented four subgenera: two species of subgenus Aria - S. aria (L.) Crantz, S. intermedia (Ehrh.) Pers., one species of subgenus Chamaemespilus -

TABLE 1. Location of studied pollen samples of Polish Sorbus species. Division into subgenera according to Phipps and the others (1990).

\begin{tabular}{|c|c|c|c|c|c|}
\hline Subgenera & $\begin{array}{l}\text { No. } \\
\text { of sample }\end{array}$ & Location & Longitude E & Latitude N & Collector, date of collection \\
\hline \multirow[t]{8}{*}{ Aria } & & S. aria (L.) Crantz & & & \\
\hline & 1 & Prov. Małopolskie, Pieniny Mts. & $20^{\circ} 24^{\prime}$ & $49^{\circ} 25^{\prime}$ & Bodziarczyk J., 25.05.2003 \\
\hline & 2 & Prov. Małopolskie, Tatra Mts. (GOB Zakopane) & $19^{\circ} 58^{\prime}$ & $49^{\circ} 17^{\prime}$ & Walusiak E., 27.05.2003 \\
\hline & & S. intermedia (Ehrh.) Pers. & & & \\
\hline & 1 & Prov. Pomorskie, 'Kępa Redłowska’ reserve & $18^{\circ} 33^{\prime}$ & $54^{\circ} 34^{\prime}$ & Szramka J., 14.05.2002 \\
\hline & 2 & Prov. Pomorskie, Kolbudy & $18^{\circ} 28^{\prime}$ & $54^{\circ} 17^{\prime}$ & Szramka J., 13.05.2002 \\
\hline & 3 & Prov. Pomorskie, Wirty & $18^{\circ} 22^{\prime}$ & $53^{\circ} 55^{\prime}$ & Bednorz L., 23.05.2002 \\
\hline & 4 & Prov. Wielkopolskie, Poznań (Dendrological Garden) & $16^{\circ} 53^{\prime}$ & $52^{\circ} 25^{\prime}$ & Bednorz L., 8.05.2002 \\
\hline \multirow[t]{13}{*}{ Sorbus } & & Sorbus aucuparia subsp. aucuparia & & & \\
\hline & 1 & Prov. Lubuskie,Słubice & $14^{\circ} 35^{\prime}$ & $52^{\circ} 21^{\prime}$ & Bednorz E., 16.05.2003 \\
\hline & 2 & Prov. Pomorskie, Słowiński National Park & $17^{\circ} 24^{\prime}$ & $54^{\circ} 44^{\prime}$ & Antkowiak W., 1.06.2003 \\
\hline & 3 & Prov. Pomorskie, Kaliska & $18^{\circ} 13^{\prime}$ & $53^{\circ} 55^{\prime}$ & Bednorz L., 23.05.2002 \\
\hline & 4 & Prov. Kujawsko-pomorskie, Jamy & $18^{\circ} 58^{\prime}$ & $53^{\circ} 31^{\prime}$ & Tarnawski A., 20.05.2002 \\
\hline & 5 & Prov. Podlaskie, Białowieża & $14^{\circ} 52^{\prime}$ & $52^{\circ} 42^{\prime}$ & Korczyk A., 16.05. 2002 \\
\hline & 6 & Prov. Wielkopolskie, Wielkopolski National Park & $16^{\circ} 48^{\prime}$ & $52^{\circ} 16^{\prime}$ & Bednorz L., 4.05.2002 \\
\hline & 7 & Prov. Wielkopolskie, Kątnik & $16^{\circ} 55^{\prime}$ & $52^{\circ} 18^{\prime}$ & Bednorz L., 5.05.2002 \\
\hline & 8 & Prov. Wielkopolskie, Tokary & $18^{\circ} 25^{\prime}$ & $52^{\circ} 23^{\prime}$ & Bednorz L., 16.05.2002 \\
\hline & 9 & Prov. Małopolskie, Babiogórski National Park & $19^{\circ} 31^{\prime}$ & $49^{\circ} 36^{\prime}$ & Bodziarczyk J., 31.05.2003 \\
\hline & & S. aucuparia subsp. glabrata (Wimm. \& Grab.) Cajander & & & \\
\hline & 1 & Prov. Małopolskie, Babia Góra & $19^{\circ} 31^{\prime}$ & $49^{\circ} 35^{\prime}$ & Bodziarczyk J., 14.06.2003 \\
\hline & 2 & Prov. Małopolskie, Tatra Mts. & $19^{\circ} 50^{\prime}$ & $49^{\circ} 14^{\prime}$ & Bednorz L., 7.07.2002 \\
\hline \multirow[t]{2}{*}{ Chamaemespilus } & & S. chamaemespilus (L.) Crantz & & & \\
\hline & 1 & Prov. Małopolskie, Tatra Mts. (GOB Zakopane) & $19^{\circ} 58^{\prime}$ & $49^{\circ} 17^{\prime}$ & Walusiak E., 23.05.2003 \\
\hline \multirow[t]{8}{*}{ Torminaria } & & S. torminalis (L.) Crantz & & & \\
\hline & 1 & Prov. Pomorskie, Borzechowo & $18^{\circ} 19^{\prime}$ & $53^{\circ} 54^{\prime}$ & Bednorz L., 23.05.2002 \\
\hline & 2 & Prov. Kujawsko-pomorskie, Jamy & $18^{\circ} 58^{\prime}$ & $53^{\circ} 31^{\prime}$ & Tarnawski A., 20.05.2002 \\
\hline & 3 & Prov. Wielkopolskie, Goraj & $16^{\circ} 31^{\prime}$ & $52^{\circ} 53^{\prime}$ & Bednorz L., 28.05.2002 \\
\hline & 4 & Prov. Wielkopolskie, 'Brzęki przy Starej Gajówce’ reserve & $16^{\circ} 28^{\prime}$ & $52^{\circ} 28^{\prime}$ & Bednorz L., 8.05.2002 \\
\hline & 5 & Prov. Wielkopolskie, 'Bytyńskie Brzęki’ reserve & $16^{\circ} 28^{\prime}$ & $52^{\circ} 28^{\prime}$ & Bednorz L., 8.05.2002 \\
\hline & 6 & Prov. Wielkopolskie, Wielkopolski National Park & $16^{\circ} 48^{\prime}$ & $52^{\circ} 16^{\prime}$ & Bednorz L., 14.05.2002 \\
\hline & 7 & Prov. Małopolskie, 'Białowodzka Góra' reserve & $20^{\circ} 38^{\prime}$ & $49^{\circ} 41^{\prime}$ & Chochliński K., 6.05.2002 \\
\hline
\end{tabular}




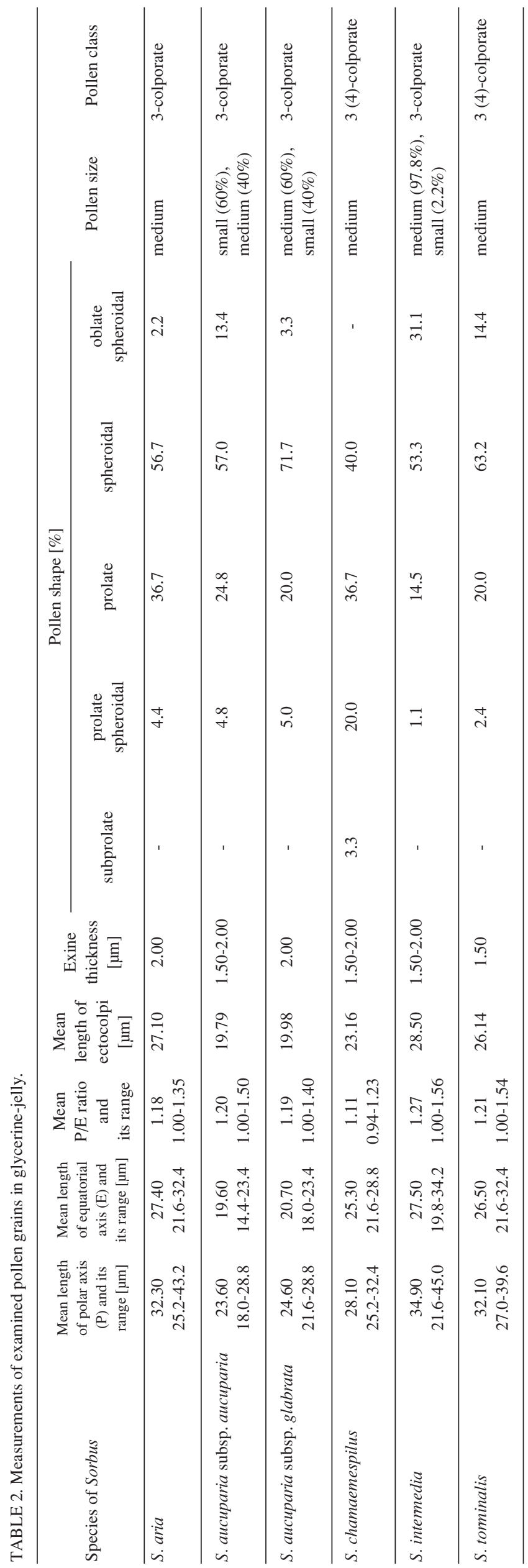

S. chamaemespilus (L.) Crantz, one species of subgenus Sorbus - S. aucuparia L. Emend. Hedl. and one species of subgenus Torminaria - S. torminalis (L.) Crantz. In accordance to $S$. aucuparia its division into two subspecies - aucuparia and glabrata (Wimm. \& Grab.) Cajander was included.

Pollen from mature anthers was collected from natural localities and sporadically from cultivated plants. The number of examined species samples (1-9) depended on their distribution range and abundance. Detailed information about the collected material is given in Table 1 .

Thirty pollen grains for each sample were investigated and 750 grains in all were observed. The following quantitative and qualitative pollen features were analysed: length of polar axis $(\mathrm{P})$, length of equatorial axis $(\mathrm{E}), \mathrm{P} / \mathrm{E}$ ratio, thickness of exine, length of ectocolpi, shape and outline of grains and the type of pollen sculpture. The results of measurements are presented in Table 2.

All samples were acetolysed according to Erdtman's method (1952), with insignificant modifications (Wrońska-Pilarek 1998). The pollen terminology follows Erdtman (1952), Reitsma (1970) and Hoen (1999). The classes of thickness of exine were fixed on the basis of its characteristic feature for some species within Rosaceae family (Eide 1981). Basing on this scale the medium thick exine has 1.46-2.09 $\mu \mathrm{m}$ of thickness.

The observations and microphotographs were performed both with scanning electron microscope (JEOL JSM 6300) and light microscopes (BIOLAR 2308, Nikon HFX-DX). The pictures of investigated grains are presented in Figures 1-6. SEM allowed to investigate the details of exine sculpture and LM was mainly used to study the exine structure.

\section{RESULTS}

Pollen grains of all investigated species were small or medium sized. On average, length of polar axis $(\mathrm{P})$ was within the interval 23.6-34.9 $\mu \mathrm{m}$ (with the whole range 18.0-45.0 $\mu \mathrm{m})$. Small grains were most often observed in samples of Sorbus aucuparia subsp. aucuparia (60\% analysed grains of this taxon) and of S. aucuparia subsp. glabrata $(40 \%)$ and only sporadically in samples of S. intermedia $(2.2 \%)$. In turn, polar axes of S. aria, S. chamaemespilus, $S$. intermedia and $S$. torminalis were usually more than $28 \mu \mathrm{m}$ long and their ranges of variability partly overlapped (Table 2).

According to the five analysed species, the $\mathrm{P} / \mathrm{E}$ value most often oscillated from 1.11 to 1.27 (with minimum 0.94 in S. chamaemespilus sample and maximum 1.56 in $S$. intermedia one). At least $50 \%$ of pollen grains in samples of $S$. aria, S. aucuparia, S. intermedia and S. torminalis had subprolate shape. This form was also characteristic for $40 \%$ of grains of S. chamaemespilus. Almost the same percentage of $S$. chamaemespilus grains were prolate spheroidal and this shape class was also often noted in samples of the other taxa. Also grains of S. chamaemespilus had a relatively large number of spheroidal forms, and grains of $S$. intermedia were sometimes distinguished by prolate shape.

Irrespective of the Sorbus species, the outline in polar view was mostly circular, more rarely triangular with obtuse apices and convex sides and in equatorial view - mostly elliptic, more rarely circular or quinquangular with obtuse apices and concave sides. 

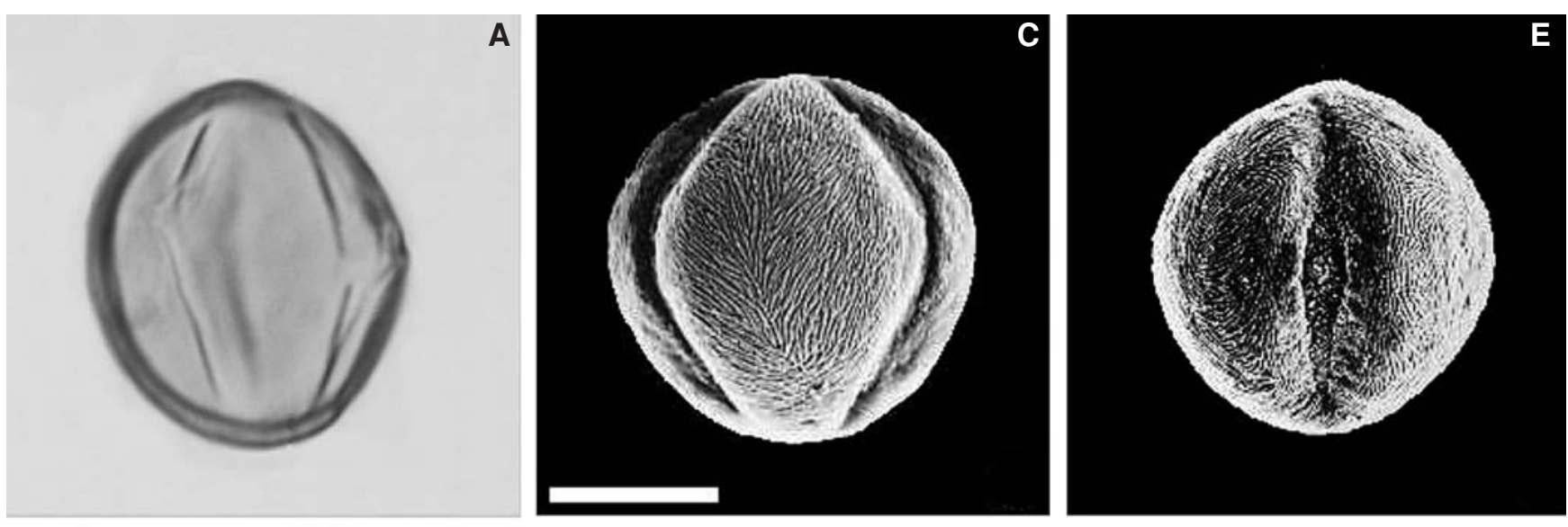

B

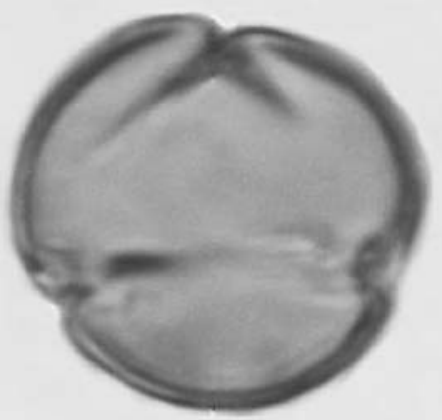

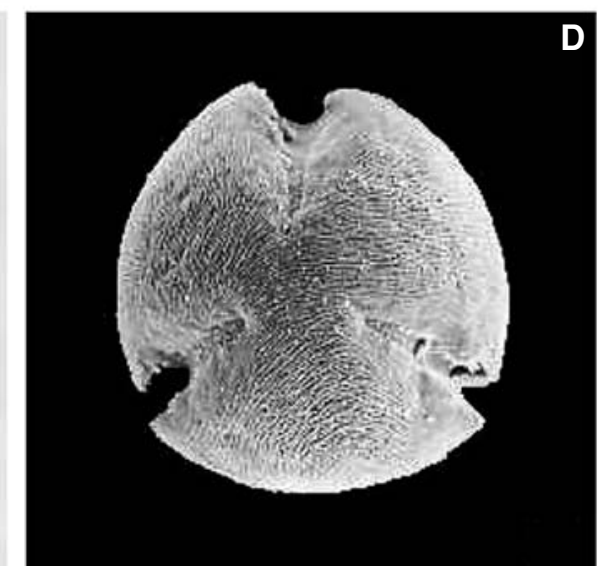

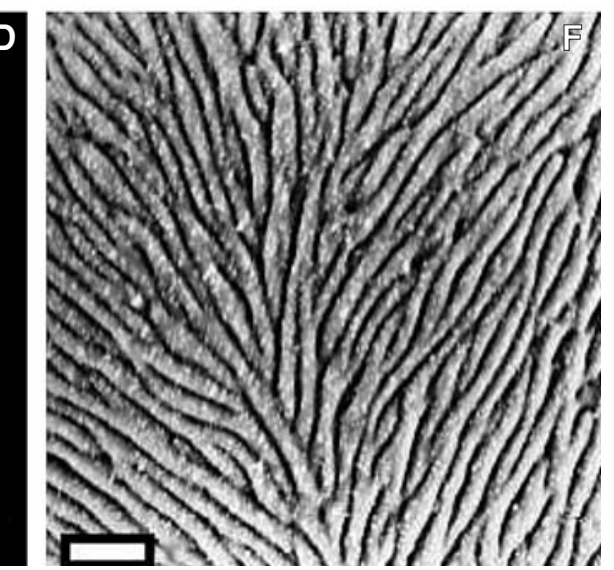

Fig. 1. Sorbus aria. A - (LM). Outline in equatorial view; 2 ectocolpi and exine structure visible $(\times 1000)$; B - (LM). Outline in polar view; exine structure, apocolpium and fragments of 3 ectocolpi visible $(\times 1000)$; $\mathrm{C}-(\mathrm{SEM})$. Outline in equatorial view; 2 ectocolpi and striate sculpture of grain visible $(\times 2000)$ white bare corresponds to $10 \mu \mathrm{m}$; D - (SEM). Outline in polar view; striate sculpture of grain, apocolpium and fragments of 3 ectocolpi visible ( $\times 2000)$; E - (SEM). Outline in equatorial view; ectocolpus and striate sculpture of grain visible $(\times 2000)$; F - (SEM). Close-up of striate sculpture of grain; striae and muri visible ( $\times 8000)$; white bare corresponds to $1 \mu \mathrm{m}$.

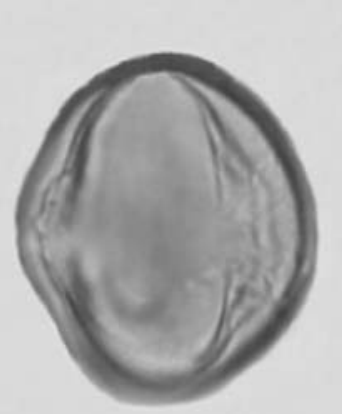

A

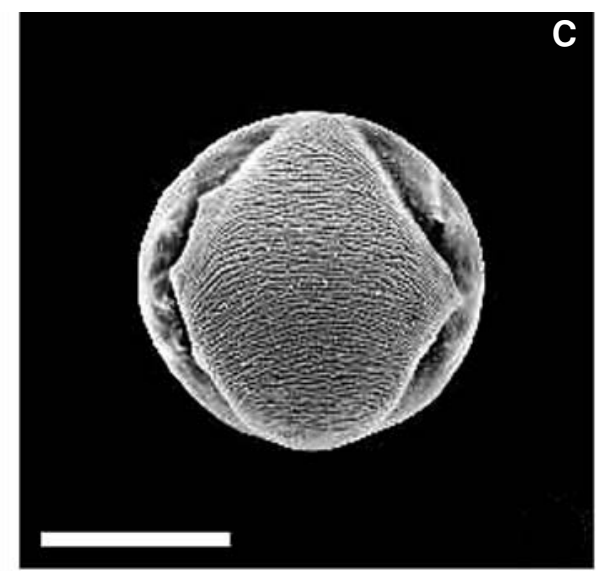

B

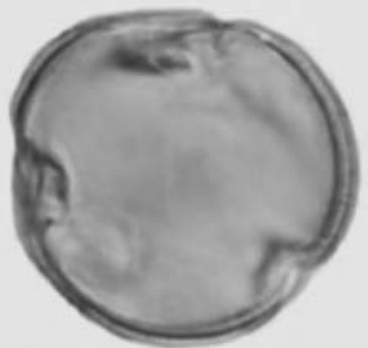

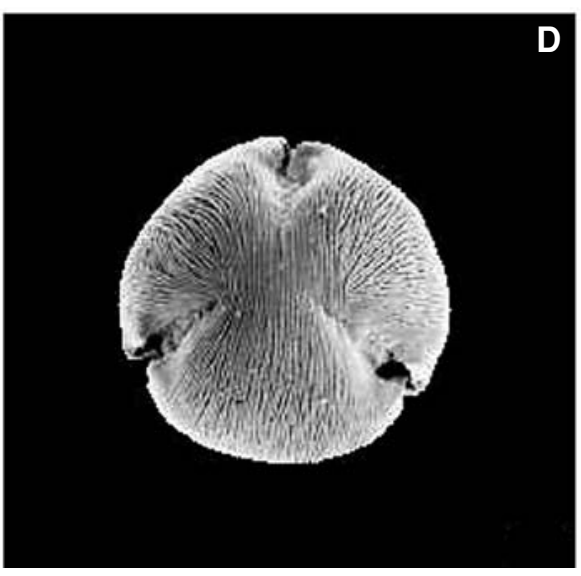

D
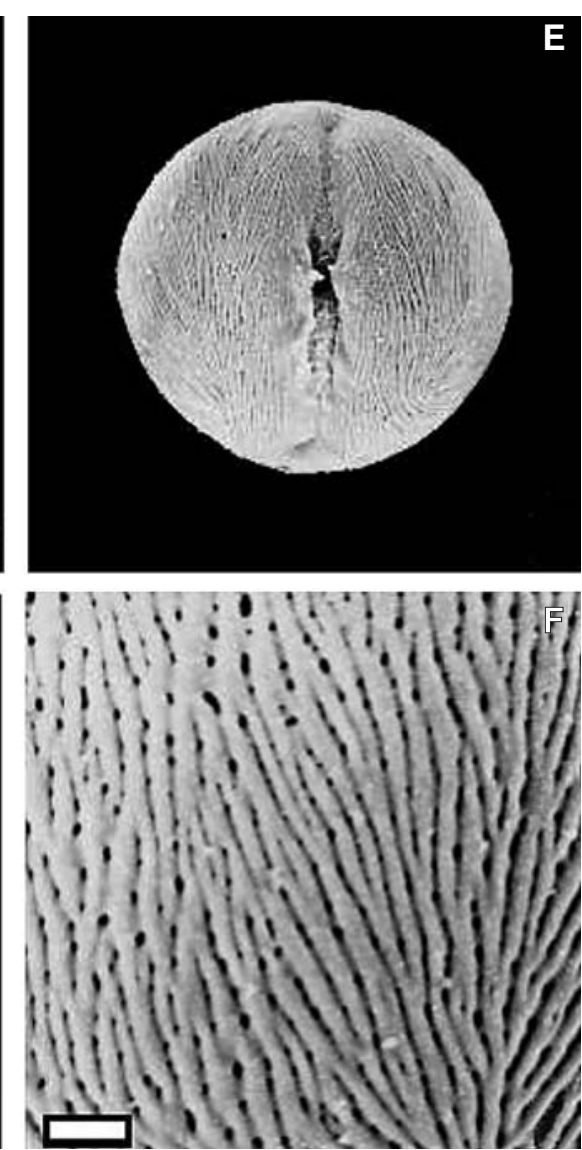

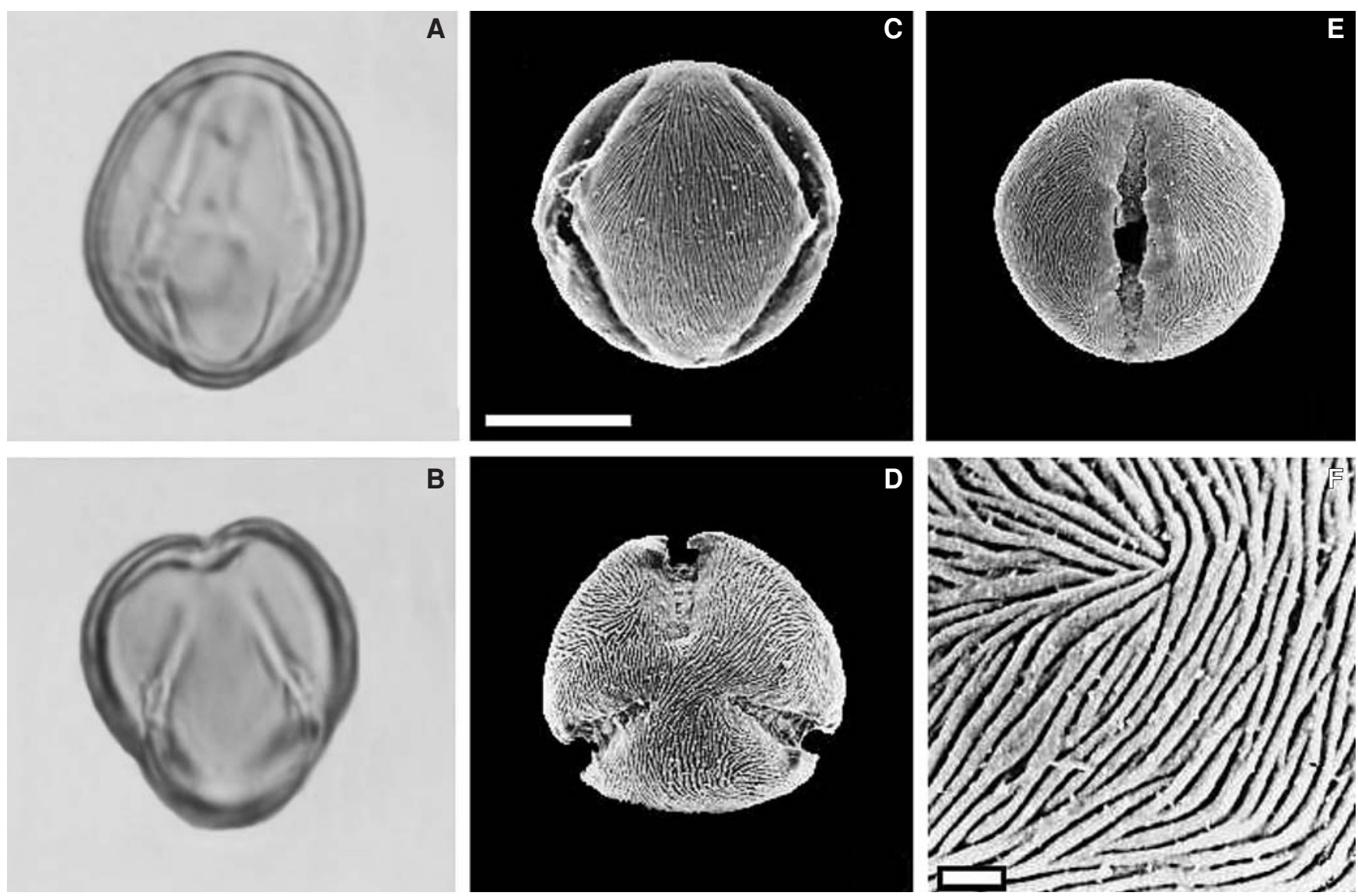

Fig. 3. Sorbus aucuparia subsp. glabrata. A - (LM). Outline in equatorial view; 2 ectocolpi and exine structure visible ( $\times 1000)$; B - (LM). Outline in polar view; exine structure, apocolpium and fragments of 3 ectocolpi visible $(\times 1000)$; $\mathrm{C}-(\mathrm{SEM})$. Outline in equatorial view; 2 ectocolpi and striate sculpture of grain visible $(\times 2000)$; white bare corresponds to $10 \mu \mathrm{m}$; D - (SEM). Outline in polar view; striate sculpture of grain, apocolpium and fragments of 3 ectocolpi visible $(\times 2000)$; E - (SEM). Outline in equatorial view; ectocolpus and striate sculpture of grain visible $(\times 2000)$; F $-($ SEM). Close-up of striate sculpture of grain; striae, muri and perforations visible $(\times 8000)$; white bare corresponds to $1 \mu \mathrm{m}$.

Three-zonocolporate pollen grains were observed in all investigated species. Besides, 4-zonocolporate grains were noted in the samples of $S$. chamaemespilus (relatively often) and of S. torminalis (rarely).

Ectocolpi had an elliptical outline and were usually relatively narrow and deeply sunken in exine, with acute ends. Ectoaperture length was more than 4/5 length of polar axis. Ectocolpus margin was irregular, slightly recurvate inwards. Membrana ectcolpi were rugulate or granulate. A bridge over ectocolpus in the equatorial region was present, well visible in LM as a central break. If there were three ectocolpi in the equatorial zone, then they were regularly arranged, the distance among them was \pm equal; if there were four ectoapertures - the distance among them was distinctly unequal. Endopori were placed in the central part of ectocolpi, circular or elliptical in outline, with irregular margins. A fastigium in the region of the endoporus was observed.

Exine always consisted of two layers, well visible in LM. Usually ectexine and endexine were of the same thickness, only in S. torminalis samples ectexine was thicker than endexine. Exine of medium thickness - 1.5-2.0 um thick.

All grains with tectum perforatum. Usually striatae type of sculpture was observed, except pollen grains of S. intermedia, which was characterized by intermediate type of sculpture, with the feature both striate and regulate ornamentation. In the striate surface relief muri were well marked, cylindrical, \pm bifurcately forked, parallel elongated to the polar axis, rarely perpendicularly, with an arrangement resembling leaf venation ( $S$. aucuparia [type and subsp. glabrata], S. aria) or forming numerous curves (S. chamaemespilus, S. torminalis). Single muri were divided by well visible striae. Striae relatively narrow, with less or more marked perforations at their bottom. Perforations of different diameters. Ornamentation of apocolpi and mesocolpi were the same. Intermediate type of sculpture was distinguished by short muri, markedly flattened, wide, irregularly arranged. Striae relatively narrow and shallow, very short, with perforations of different diameters, rather poorly visible. Ornamentation of apocolpi and mesocolpi similar.

Fig. 2. Sorbus aucuparia subsp. aucuparia. A - (LM). Outline in equatorial view; 2 ectocolpi and exine structure visible $(\times 1000)$; B - (LM). Outline in polar view; exine structure, apocolpium and fragments of 3 ectocolpi visible $(\times 1000)$; C $-(\mathrm{SEM})$. Outline in equatorial view; 2 ectocolpi and striate sculpture of grain visible $(\times 2000)$; white bare corresponds to $10 \mu \mathrm{m} ; \mathrm{D}-(\mathrm{SEM})$. Outline in polar view; striate sculpture of grain, apocolpium and fragments of 3 ectocolpi visible $(\times 2000)$; E - (SEM). Outline in equatorial view; ectocolpus and striate sculpture of grain visible $(\times 2000)$; F - (SEM). Close-up of striate sculpture of grain; striae, muri and perforations visible $(\times 8000)$; white bare corresponds to $1 \mu \mathrm{m}$. 

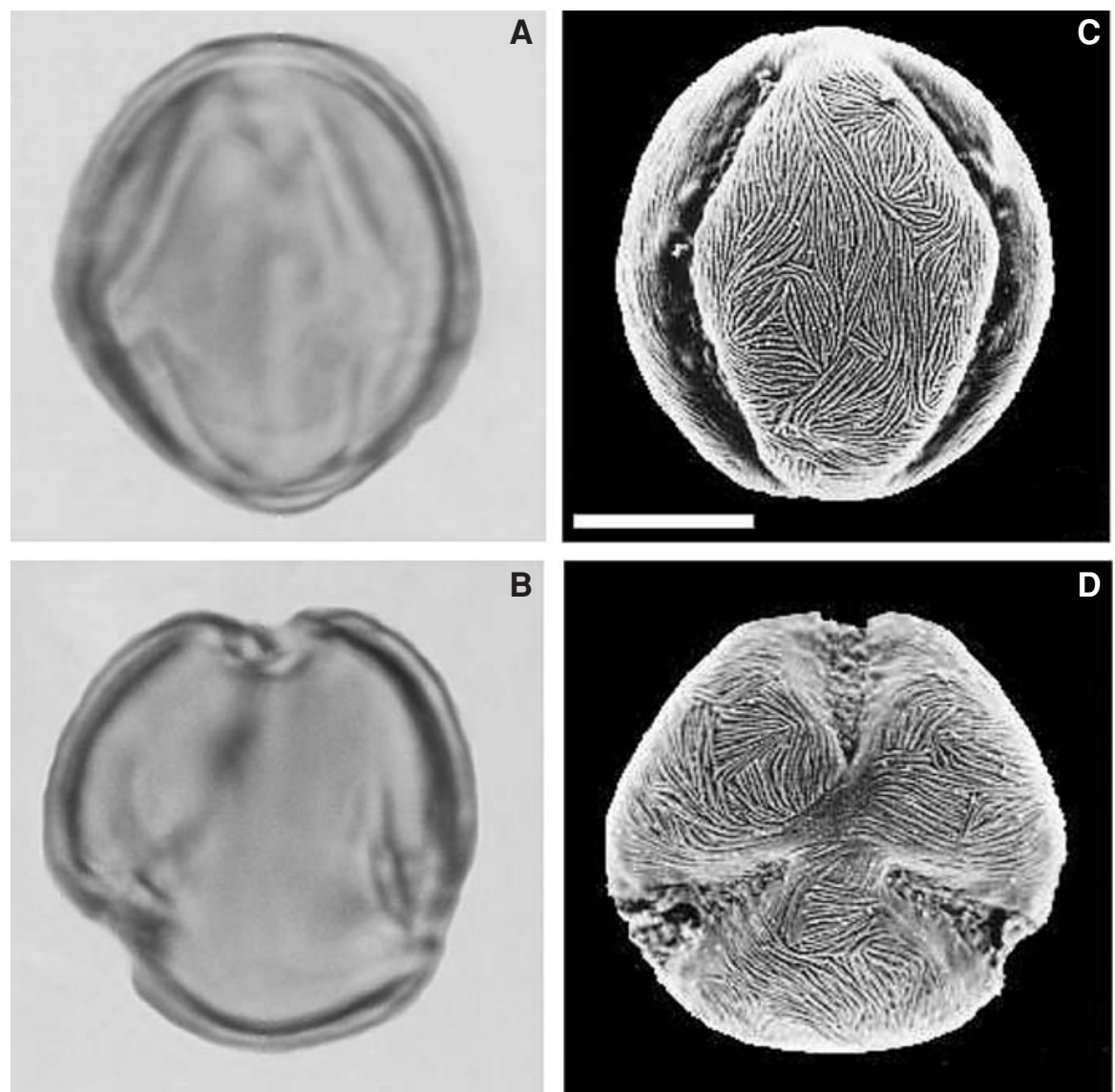

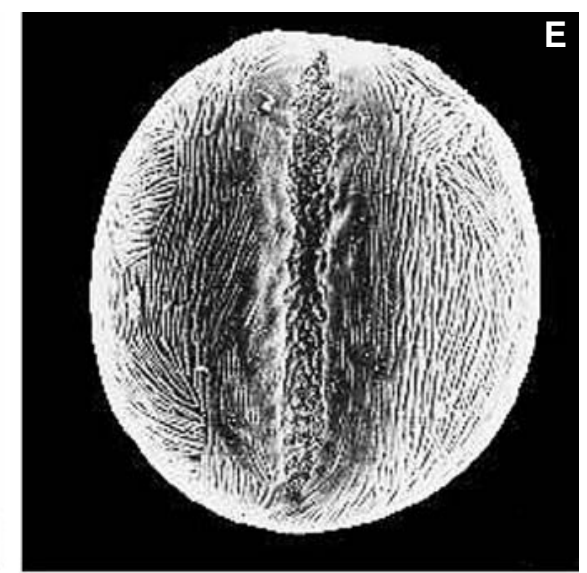

D

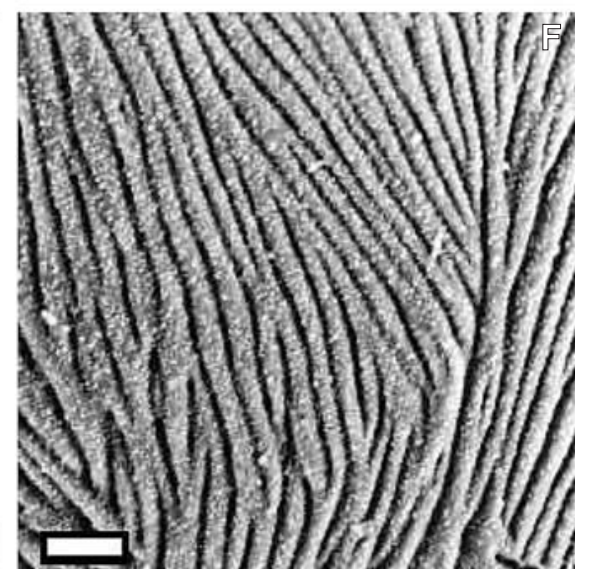

Fig. 4. Sorbus chamaemespilus. A - (LM). Outline in equatorial view; 2 ectocolpi and exine structure visible $(\times 1000)$; B $-(\mathrm{LM})$. Outline in polar view; exine structure, apocolpium and fragments of 3 ectocolpi visible $(\times 1000)$; $\mathrm{C}-(\mathrm{SEM})$. Outline in equatorial view; 2 ectocolpi and striate sculpture of grain visible ( $\times 2000)$; white bare corresponds to $10 \mu \mathrm{m}$; D - (SEM). Outline in polar view; striate sculpture of grain, apocolpium and fragments of 3 ectocolpi visible (×2000); E - (SEM). Outline in equatorial view; ectocolpus and striate sculpture of grain visible $(\times 2000)$; F $-($ SEM). Close-up of striate sculpture of grain; striae, muri and perforations visible $(\times 8000)$; white bare corresponds to $1 \mu \mathrm{m}$.
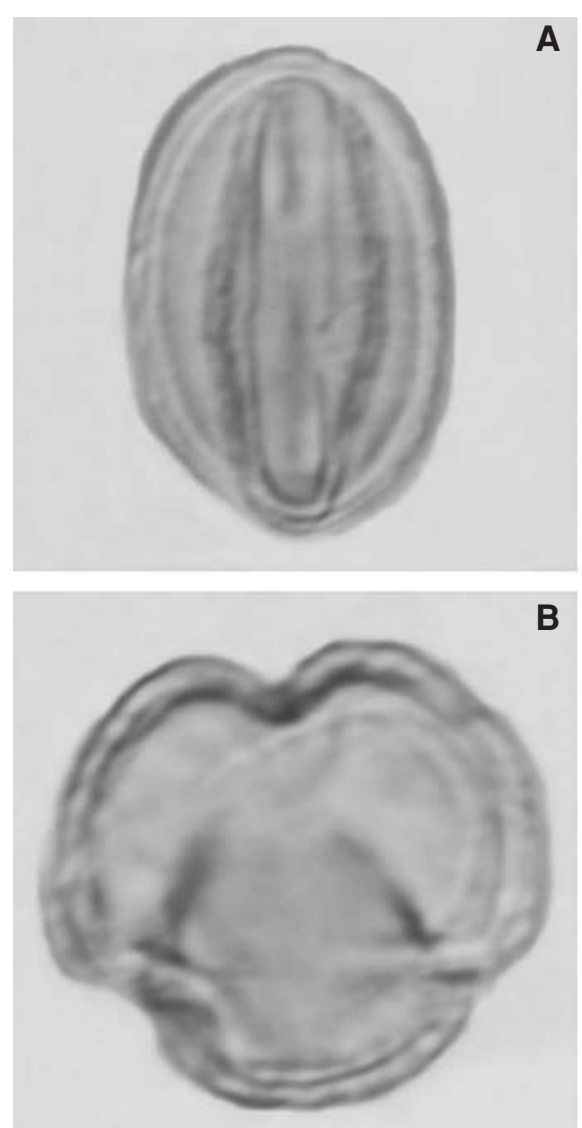

B
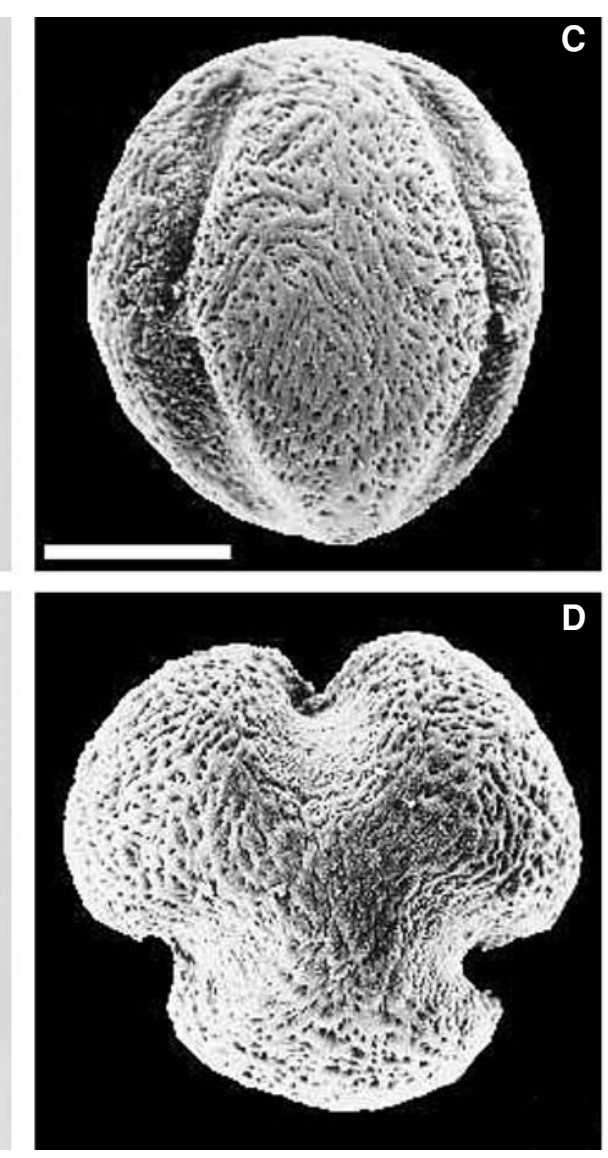
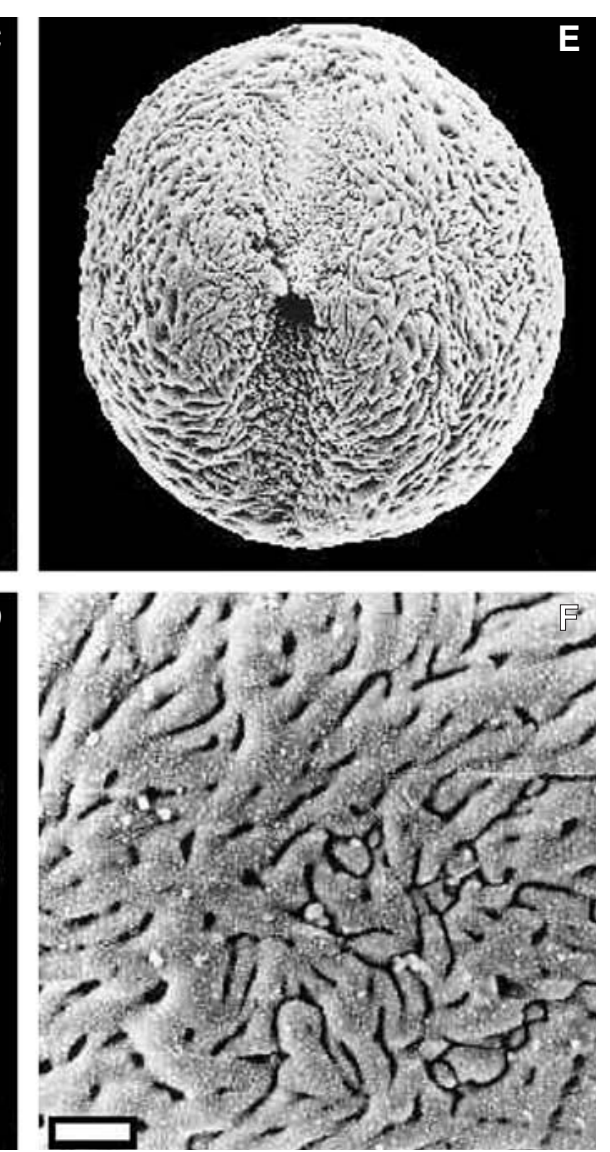

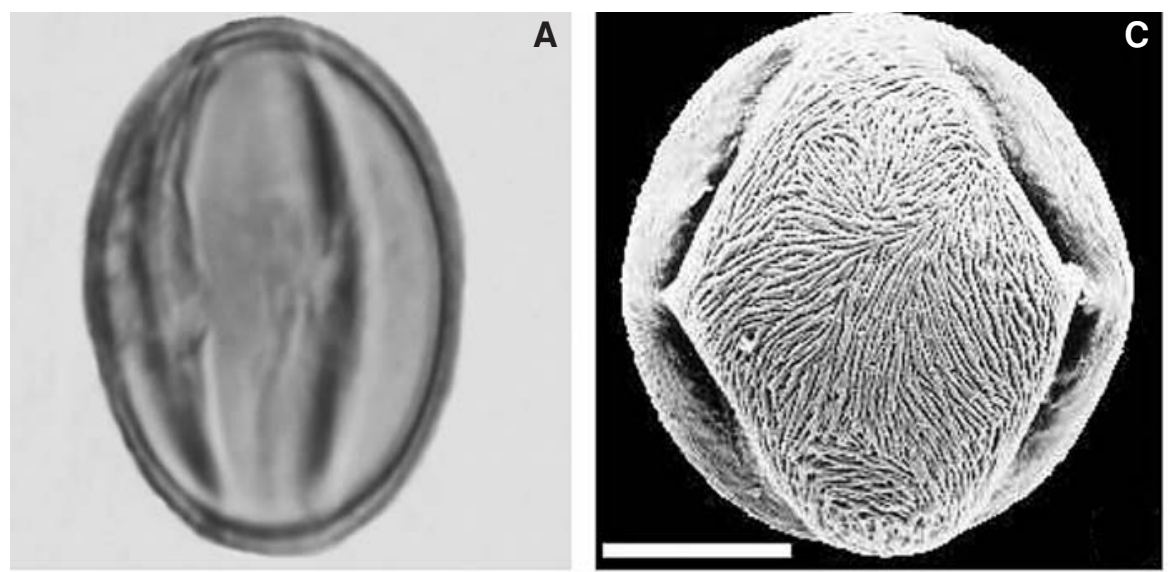

B
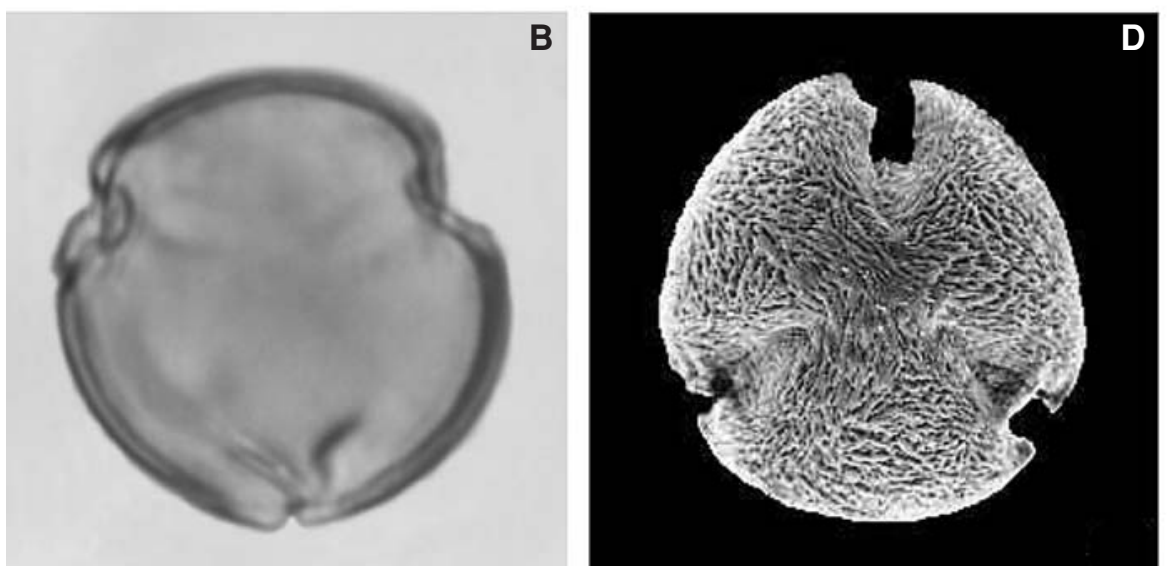
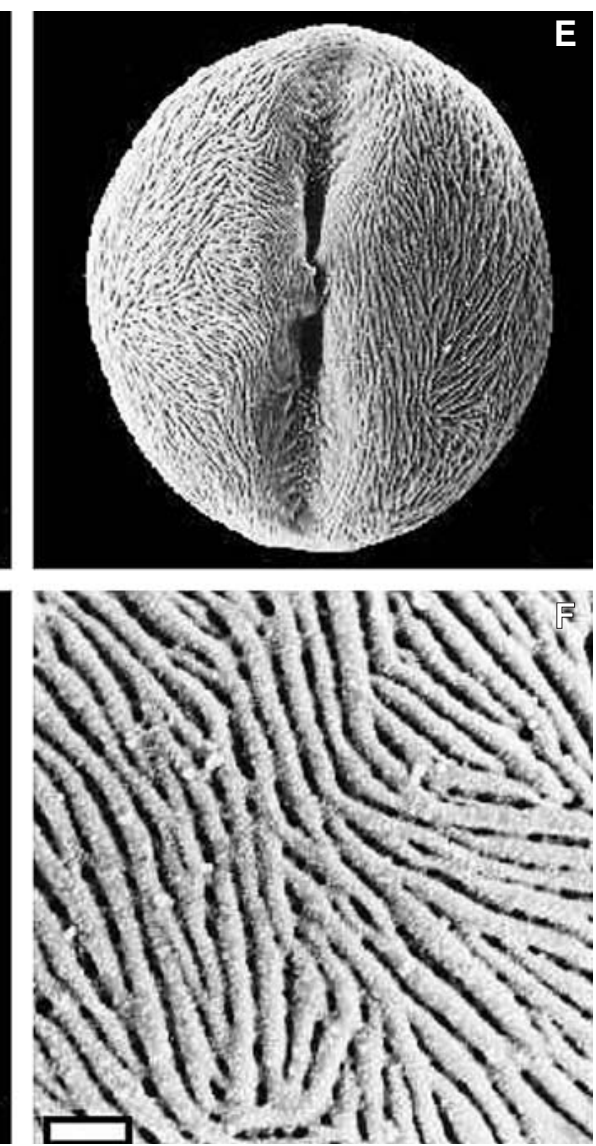

Fig. 6. Sorbus torminalis. A - (LM). Outline in equatorial view; 2 ectocolpi and exine structure visible $(\times 1000)$; B $-(\mathrm{LM})$. Outline in polar view; exine structure, apocolpium and fragments of 3 ectocolpi visible $(\times 1000)$; $\mathrm{C}-(\mathrm{SEM})$. Outline in equatorial view; 2 ectocolpi and striate sculpture of grain visible $(\times 2000)$; white bare corresponds to $10 \mu \mathrm{m}$; D - (SEM). Outline in polar view; striate sculpture of grain, apocolpium and fragments of 3 ectocolpi visible ( $\times 2000)$; E - (SEM). Outline in equatorial view; ectocolpus and striate sculpture of grain visible $(\times 2000)$; F - (SEM). Close-up of striate sculpture of grain; striae, muri and perforations visible $(\times 8000)$; white bare corresponds to $1 \mu \mathrm{m}$.

\section{KEY TO POLISH SPECIES OF SORBUS, BASED ON POLLEN MORPHOLOGY}

1. Intermediate sculpture between striate and rugulate. Muri markedly flattened, wide, short irregularly arranged. S. intermedia

$1 *$. Striate sculpture. Muri cylindrical, narrow, elongated, regularly arranged

2. Grains small or medium size, usually polar axis (18.0-)23.6-24.6(-28.8) um long; only 3-zonocolporate pollen grains. S. aucuparia

$2 *$. Grains of medium size, rarely small, usually polar axis (21.6-)28.1-32.3(-45.0) um;

besides 3-zonocolporate pollen grains,

sometimes 4-zonocolporate ones observed........... 3 .

3. Muri \pm straight, most often bifurcately forked ..... S. aria $3^{*}$. Muri forming numerous curves. 4.

4. Ectexine and endexine of equal thickness S. chamaemespilus $4^{*}$. Ectexine thicker than endexine S. torminalis

\section{DISCUSSION}

Moore and others (1991), basing on endoaperture structure, sculpture, shape and size of grains, divided the investigated species of Sorbus (together with other representatives of Maloideae subfamily) into two groups. One of those among other taxa included S. aucuparia and S. torminalis, the second one $-S$. aria and poliploids of genus (with $S$. intermedia too). Present investigations have not confirmed correctness of such classification. However, striate sculpture is a common feature in S. aucuparia and S. torminalis, both species differ in structure details of this ornamentation. Exine surface of $S$. aucuparia with the \pm rectilinearly arranged muri rather resembles the sculpture of $S$. aria, than of ornamentation of $S$. torminalis, with curved muri.

In turn, in accordance with the systematic classification of Phipps and others (1990), Sorbus aria and S. intermedia belong to the Aria subgenus. The present study reveals completely different types of exine sculpture in those species: striatae type characteristic for grains of $S$. aria, as mentioned above with the features similar ornamentation

Fig. 5. Sorbus intermedia. A - (LM). Outline in equatorial view; 2 ectocolpi and exine structure visible $(\times 1000)$; B $-(\mathrm{LM})$. Outline in polar view; exine structure, apocolpium and fragments of 3 ectocolpi visible $(\times 1000)$; C $-($ SEM $)$. Outline in equatorial view; 2 ectocolpi and intermediate sculpture of grain visible $(\times 2000)$; white bare corresponds to $10 \mu \mathrm{m}$; D - (SEM). Outline in polar view; intermediate sculpture of grain, apocolpium and fragments of 3 ectocolpi visible $(\times 2000)$; E - (SEM). Outline in equatorial view; ectocolpus and intermediate sculpture of grain visible $(\times 2000)$; F $-(S E M)$. Close-up of intermediate sculpture of grain; irregular striae and muri visible $(\times 8000)$; white bare corresponds to $1 \mu \mathrm{m}$. 
of $S$. aucuparia and intermediate type observed exclusively in grains of S. intermedia. Jankun (1993) ascertained S. intermedia to be a tetraploid hybrid, consisting of two genomes of $S$. aria, one of $S$. aucuparia and one of $S$. torminalis. Considering the character of exine ornamentation, no evidence of relationship among $S$. intermedia and three other species, from which it probably has been derived, has been found.

In the current study no significant differences in shape of grains among the analysed Sorbus species have been noted. All taxa had \pm elongated polar axis and only $1 / 5$ pollen grains of $S$. chamaemespilus were spheroidal. Whereas, in accordance with Moore's and others observations (1991), S. aucuparia and S. torminalis were narrowly elliptic, unlike the group with $S$. aria, having only slightly longer than broad pollen grains. The authors of this paper have not confirmed Eide's observation (1981) either, who noted that pollen grains of $S$. aucuparia are more oblate than other Sorbus species. However, it is necessary to remember that the shape of grains considerably depends on the method of pollen preparation.

Generally, pollen size is thought to be a diagnostic feature of little reliability. Such an opinion results from the variability of pollen grains of Rosaceae (Moore at al. 1991) and from the method of acetolysis (Reitsma 1969). Nevertheless, comparing our results with the data from palynological literature, it is still possible to ascertain some regularities. Pollen grains of $S$. intermedia were usually larger than the grains of other observed species (from \pm 2 to \pm 8 $\mu \mathrm{m})$. Similar value of grain dimensions of this taxon was noted by Praglowski (1962). It confirms Moore's and others' observation (1.c.), that grains of poliploid species are used to be greater than those of diploids. In turn, pollen grains of S. aucuparia (both subsp. aucuparia and glabrata) were small, with the polar axis no longer than $25 \mu \mathrm{m}$. Almost the same results for this species were obtained by Eide (1981), Boyd and Dickson (1986) and Moore and others (1. c.). Length of polar axis (P) of grains of this taxon noted by Praglowski (1962) and Stachurska and others (1973), was $\pm 2 \mu \mathrm{m}$ greater.

The aperture structure of pollen grains of the described species may be a controversial question too. For example the authors of the current study did not observe star-shaped endoapertures, according to Moore and others (1991), being characteristic features of grains of S. aucuparia and S. torminalis. Such a type of endoaperture has not been mentioned in any other palynological elaboration of genus Sorbus.

\section{CONCLUSIONS}

Pollen morphology of the investigated species of Sorbus corresponds with their systematic classification. It is relatively easy to separate pollen grains of the following subgenera: Sorbus, Chamaemespilus and Torminaria. Only subgenus Aria includes grains of different morphology, and therefore it is impossible to determine the diagnostic features of this subgenus. Pollen morphology does not confirm a close relationship between $S$. aria and $S$. intermedia.

The presented study allowed to determine some diagnostic features of pollen grains of each investigated species. Type of sculpture, length of polar axis, number of ectocolpi, ratio of ectexine to endexine thickness are the most im- portant ones. It is possible to distinguish the pollen grains of all the analysed native species, but only using SEM. However, there are no important differences in pollen morphology between the subspecies of Sorbus aucuparia.

\section{AKNOWLEDGEMENTS}

We would like to thank the following persons who helped us in preparing the plant material, taking microphotographs and preparing pictures: Dr Mirosław Makohonienko (Adam Mickiewicz University, Poznań), Dr Dariusz J. Gwiazdowicz and Mirosław Dziurla (both Agricultural University, Poznań). We would like to express our gratitude to Professor Jerzy Zieliński (Agricultural University, Poznań), for his critical comments of the manuscript. We also thank all these, who helped us to collect plant material.

\section{LITERATURE CITED}

BOYD W.E., DICKSON J.H. 1986. The pollen morphology of four Sorbus species, with special reference to two Scottish endemic species, S. arranensis Hedl. and S. pseudofennica E.F. Warb. Pollen Spores 29: 59-71.

EIDE F. 1981. Key for Northwest European Rosaceae Pollen. Grana 20: 101-118.

ERDTMAN G. 1952. Pollen Morphology and Plant Taxonomy. Angiosperms. An introduction to palynology 1. Almqvist \& Wiksell, Stockholm.

FAEGRI K., IVERSEN J. 1964. Textbook of pollen analysis. Munksgaard, Copenhagen.

FAEGRI K., IVERSEN J. 1992. Textbook of pollen analysis. John Wiley and Sons. Chichister, New York, Brisbane, Toronto, Singapore.

GABRIELIAN E. 1978. The genus Sorbus in Western Asia and the Himalayas. Izdatielstvo Akademii Nauk Armianskoj SSR, Erevan. (in Russian with English summary)

HOEN P. 1999. Glossary of Pollen and Spore Terminology. http: //www.bio.uu.nl/ palaeo/glossary/index.htm

JANKUN A. 1993. Znaczenie apomiksji w ewolucji rodzaju Sorbus (Rosaceae). Fragm. Flor. Geobot. 38, 2: 627-686. (in Polish with English summary)

MOORE P.D., WEBB J.A., COLLINSON M.E. 1991. Pollen analysis. Blackwell Scientific Publications. Oxford.

PHIPPS J.B., ROBERTSON K.R., SMITH P.G., ROHRER J.R. 1990. A checklist of the subfamily Maloideae (Rosaceae). Can. J. Bot. 68: 2209-2269.

PRAGLOWSKI J. 1962. Notes on the pollen morphology of Swedish trees and shrubs. Grana Palynologica 3, 2: 45-65.

REITSMA T. 1966. Pollen morphology of some European Rosaceae. Acta Bot. Neerl. 15: 290-307.

REITSMA T. 1969. Size modification on recent pollen grains under different treatments. Rev. Paleobot. Palynol. 9: 175-202.

REITSMA T. 1970. Suggestions towards unification of descriptive terminology of angiosperm. Pollen grains. Rev. Paleobot. Palynol. 10: 39-60.

STACHURSKA A., SADOWSKA A., KUSZELL T. 1973. Sorbus aucuparia L., Jarząb pospolity (jarzębina), Sorbus domestica L., Jarząb domowy, Sorbus aria (L.) Cr., Jarząb mączny, Sorbus chamaemespilus (L.) Cr., Jarząb nieszypułkowy, Sorbus torminalis (L.) Cr., Jarząb brekinia (brzęk), (Rosaceae). Kartoteka palynologiczna roślin polskich. Zeszyty Przyrod. Opol. Tow. Przyj. Nauk 13: tab. 204-208. (in Polish with English summary)

TEPPNER H. 1965. Zur Kenntnis der Gattung Waldsteinia. I. Schlüssel zum Bestimmen von Rosaceen - Pollen einschliesslich ähnlicher Pollenformen aus anderen Familien. Phyton 34: 224-238.

WROŃSKA-PILAREK D. 1998. Pollen morphology of the Polish species of the genus Ribes L. Acta Soc. Bot. Pol. 67, 3-4: 275-285. 